\title{
Pompeii on 79 AD: the natural landscape.A new approach for visiting an archaeological site
}

\begin{abstract}
When visiting an archaeological site, the integration of archaeology, history and geology can allow a different or more complete interpretation to the finds. Therefore a new approach to archaeological sites is proposed: a reconstruction of natural scenery as a new key of reading. The reconstruction of the natural scenery of the Pompeian territory in AD 79 is the example shown. Pompeii was built on a hill made of lava from Vesuvius, therefore more elevated in respect of the surrounding plain. The coastline, roughly parallel to the present-day one, was stretched about $1 \mathrm{~km}$ southwest of the Sea Gate. Two gentle hills represented older coastlines, and between them, to the south of the mouth of the Sarno River, there were limited marshy areas, linked to last segment of the river. Towards the east Pompeii was surrounded by cultivated fields that, with the so-called Rustics Villas, fitted well within the socioeconomic framework of the city, before the eruption. The water supply was ensured by an artificial canal discovered north of Pompeii. But this supply system was dangerous for the city that was hit by two floods that caused severe damage, including collapsed housing as shown by the geological analysis carried out in the archaeological excavation in the archaic city.
\end{abstract}

Keywords: geological stratigraphy, geoarchaeology, natural landscape, archaeological site, pompeii
Volume 2 Issue 2 - 2018

\author{
Maria Rosaria Senatore \\ Department of Science and Technology, University of Sannio, \\ Italy
}

Correspondence: Maria Rosaria Senatore, Department of Science and Technology, University of Sannio, Italy, Tel +390824 305191,Email senatore@unisannio.it

Received: February 14, 20I8 | Published: March 29, 2018

\section{Introduction}

The characteristics of sedimentary rocks, in addition to providing significant elements to reconstruct the history of a city or territory, allow, through a scientific approach, an enhancement of the naturalistic and archaeological heritage. Consequently, it is particularly interesting for the dissemination activities and to propose a new approach to archaeological sites: a reconstruction of natural scenery by integrating archaeological knowledge with geological data.

The stratigraphic and sedimentological research in Pompeii and its territory were aimed to identify the natural environment and its evolution over time by analysing samples collected from about 100 drilled boreholes starting from the present-day topographic surface to a depth of between $10 \mathrm{~m}$ and $30 \mathrm{~m}$. In temporal terms, they start from the present-day sediment and gradually cross sediments that represent earlier times. The chrono-stratigraphical framework of reference for the reconstruction of the temporal evolution of natural environment was the layer of pyroclastic deposits of the AD 79 eruption Sigurdsson et al. ${ }^{1}$ and, more in depth, the layer of pyroclastic deposits of an earlier Vesuvian eruption dated about 3960 years BP Rolandi et al. ${ }^{2}$

\section{Discussion}

Many hypotheses on the natural landscape around Pompeii have been advanced over time, often based on the reading of historical texts or on the interpretation of archaeological findings, such as planking of boats or anchors. The most debated topics were the positioning of the coastline and the course of the last segment of the Sarno River. ${ }^{3-12}$ The last segment of the Sarno River today flows about $1 \mathrm{~km}$ towards the south-east edge of the ancient city, with a rectified course made in the Bourbon period (16th century). In the natural scenery of the Pompeian territory reconstructed by Senatore et al., ${ }^{12,13}$ (Figure 1), it flowed in the same position, with an irregular pattern. The reconstruction in fact highlights the presence of large bends before the mouth that, compared to the present-day one, was about $1,3 \mathrm{~km}$ inland. The bends of the river developed between two hills, a few meters higher in respect to the surrounding plain. The hills, elongated parallel to the coast, were two coastal ridges, representing ancient coastlines: the oldest one, Messigno, which has a radiocarbon age of 5,600 years BP Barra ${ }^{14}$ and the more recent one, Bottaro, which has radiocarbon age of about 3,610 years BP Barra ${ }^{14}$ The last one stretched out in front of the ancient city. A bend of the river touched the Bottaro ridge on which Roman building used as a marine warehouse and considerable quantities of ceramic fragments have been found Ruggiero, ${ }^{15}$ D'Ambrosio. ${ }^{16}$ Near the mouth of the river up to the Messigno ridge, there was a large marshy area not connected to the sea. Since the sediment representing this natural environment contains abundant organic material it had to be rich in vegetation. In addition, the widespread discovery of poplar trunks Ruggiero ${ }^{15}$ hygrophilous species used in Roman times to dry damp soils, it was possible to state that the harbour of Pompeii, whose presence is known by historical texts, was fluvial, probably placed in one of the last bends of the river.

The submerged delta of the Sarno was very wide and fanned out to the southwest. The coastline, over $1 \mathrm{~km}$ inland and roughly parallel to the present-day one, stretched about $1 \mathrm{~km}$ southwest of the Sea Gate; between the Bottaro ridge and the shoreline, there was a narrow strip taken up mainly by vineyards De Carolis et al. ${ }^{11}$ next to this land strip there was the active beach.

The natural landscape that has been outlined is, therefore, a flat coastal area, with a lava flow hill on which the ancient Pompeii was founded. Towards the east, Pompeii was surrounded by cultivated fields, as sediment attributed to a soil is present, and, in many archaeological excavations, ploughed furrows for agricultural were 
found. The widespread presence of cultivated areas with the so-called Rustics Villas, where livestock farms were situated, where pigs and sheep were farmed, fits well within the socioeconomic framework of the city that, before the eruption, was densely populated (it is believed by about twenty thousand people).

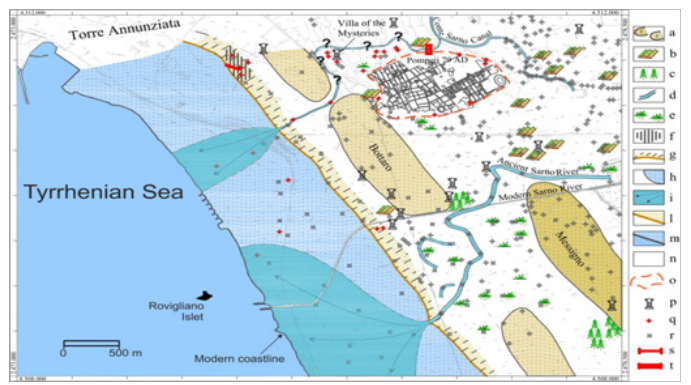

Figure I Paleogeographic map, based on integrated geological and archaeological analyses, showing the reconstruction of the natural scenery at Pompeii prior to the 79A.D.Vesuvius eruption. (a) Coastal ridges: I-Messigno (5600 yr B.P.), 2-Bottaro (3610 yr B.P.);(b) Plough furrows; (c) Poplars; (d) River channel; (e) Marsh; (f) Salt pan; (g) Emerged beach; (h) Submerged coastal margin; (i) Submerged delta; (I) 79 A.D. coastline; (m) Present day coastline; (n) No data; (o) Edge of Pompeii excavations; (p) 79 A.D. archaeological structures; (q) Boreholes between 1996and 2007; ( $r$ ) Boreholes before 1996; (s) GPR profile; (t) ERT profile. Modified from Senatore et al. ${ }^{12}$

The source of water supply is the next target. There were wells in the city, but they were not enough for the needs of such a large population, and the Sarno River was far from Pompeii and at a lower topographic elevation. To the east of Villa of the Mysteries, the last segment of an artificial canal has been identified, flowing north of the ancient city; a segment of the canal from the Sea Gate to the coastline and its submerged delta were identified by the study of the sediment collected from the boreholes (Figure 1). They were active before the eruption of AD 79 and do not exist at present. An archaeological excavation performed outside the Capua Gate Sakai, ${ }^{17}$ Matsui et al. ${ }^{18}$ has brought to light the canal filled by the deposits of the AD 79 eruption (Senatore et al., 2014). This canal, that began at a large bend in the stream to the northeast of the city, was probably created to bring water into the city. ${ }^{11,12}$

An electric tomography (ERT) was performed on the unexcavated dig-front of the archaeological excavation outside the Capua Gate and was extended into the archaeological area. The electric tomographies show the degree of humidity up to the water content present in the sediment and in the rocks. The filling sediment of the canal and its levees was averagely wet; towards the archaeological area, the tomography highlighted two structures with high humidity or water content which, due to their circular shape, were respectively referred to as a water catchment basin and a duct. The latter, oriented towards the interior of the city, was related to the city's water distribution system Senatore et al. ${ }^{12}$ At this point it is significant to outline the elevation within Pompeii: the higher elevations, around $40 \mathrm{~m}$ above sea level, are recorded in the area between the Vesuvius Gate and Capua Gate. From this area, first gently and then with a steep slope, the elevations decrease progressively until reaching the coastal plain at the Stabia Gate. This altimetric trend makes clear how this area, Capua Gate, was crucial for the organization of the Pompeii water system: the water entered through the duct, and, via gravity, could be distributed to all parts of the city.
Therefore the artificial canal represented a precious resource for Pompeii, but over time it became dangerous. In the boreholes carried out along the northern walls and in archaeological excavations in the archaic sector of the ancient city of Pompeii Senatore et al., ${ }^{12}$ (Figure 2), the sediments constitute layers with a lenticular shape and a thickness between several centimetres and about $5 \mathrm{~m}$, consisting of volcanic sand in which well-rounded limestone pebbles, volcanic pebbles and fragments of ceramics and animal bones, often oriented according to an oblique lamination are found. These deposits, distributed over a large area with a north-south trend, almost orthogonal to the course of the canal, have been interpreted as mud or debris flows released by particularly intense flooding events. ${ }^{12-13}$ The stratigraphic analysis allowed the definition of three different alluvial units, separated either by constructed levels or by root systems (Figure 2). The oldest unit (unit a) is distributed over the entire area with a thickness between $1 \mathrm{~m}$ and $5 \mathrm{~m}$ and forms a layer above the lava and on which the archaic part of Pompeii was built. A fragment of animal bone collected from this unit, dated by radiocarbon method, gave a calibrated age Stuiver et al. ${ }^{19}$ of 764 years BC. The intermediate unit (unit b) is distributed both inside and outside the city, with an average thickness of about $2 \mathrm{~m}$. In an excavation carried out in the archaic city (Figure 2), it shows a strongly erosive base that cuts the floor of a first dwelling unit and then a subsequent dwelling was built on this. Therefore, it seems likely that this alluvial flow caused the collapse of the walls and the destruction of many houses, which were subsequently rebuilt by raising the floor above the alluvial deposits. The most recent unit (unit c) is distributed in the northern city, with an average thickness of about $1 \mathrm{~m}$. A borehole carried out close to the Villa of Mysteries (S3 in Figure 2), started from the road in use in AD 79, crossed alluvial deposits of unit $\mathrm{c}$, about $2 \mathrm{~m}$ thick, and then another road in use in previous times was found.

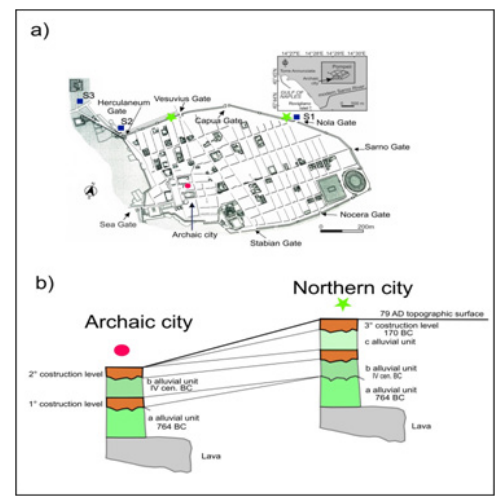

Figure 2 The Archaeological site of Pompeii (a) and stratigraphic logs of the alluvial units cropping out in the ancient city (b). Red dot and green star represent the location of the logs. b modified from Ciarallo et al. ${ }^{23}$

The presence of rounded limestone pebbles in the three units shows that these alluvial flows came from the calcareous mountains that border the plain of the river Sarno. According to Senatore et al. ${ }^{12}$ the high-density flows that were generated on May 5, 1998 in the city of Sarno Del Prete et al. ${ }^{20}$ Pareschi et al. ${ }^{21}$ or even those that in 1954 hit the cities of Cava dei Tirreni, Vietri and Salerno Esposito et al. ${ }^{22}$ developed after intense rains, and they are the modern analogue of the flows, identified by the analysis of sediments, which caused significant damage to Pompeii before its definitive disappearance due to the eruption of Vesuvius in AD 79. 


\section{Conclusion}

The reconstruction of the natural scenery of the Pompeian territory in $\mathrm{AD} 79$ made it possible to understand the meaning of some constructive choices that can be observed by visiting the ancient Pompeii and which are not normally emphasized. For example, the roads and the water conducts present at the side of the roads are organized in such a way as to drain the water in all parts of the city. Even the fountains that are located from the Vesuvius Gate to Stabia Gate, along the axis of maximum slope, are organized in order to exploit gravity. Therefore, visiting the ancient city integrating archaeology, history and geology represents a new and interesting approach to an archaeological site.

\section{Acknowledgement}

I wish to thank Luigi Buffone, Antonio Stampone and Gennaro Di Martino from the Applied Research Laboratory of the Pompeii Archaeological Park, Adrienne and Jean-Daniel Stanley, and Agostino Meo for the stimulating discussions. I am grateful to Maria D'Orsi for the English revision and to the anonymous reviewer for the improvement of the manuscript.

\section{Conflict of interest}

None.

\section{References}

1. Sigurdsson H, Carey S, Cornell W, et al. The eruption of Vesuvius in A.D 79. National Geographic Research and Exploration. 1985;1:332-387.

2. Rolandi G, Petrosino P, McGeehin J, et al. The interplinian activity at Somma-Vesuvius in the last 3500 years. Journal of Volcanology and Geothermal Research. 1998;82(1-4):19-52.

3. Ward-Perkins JB. Note di topografia e urbanistica. In: Zevi F, editor Raccolta di studi per il $19^{\circ}$ centenario dell'eruzione vesuviana Pompei 79. $1984 ; 25-39$.

4. Cinque A, Russo F. La linea di costa del 79 d.C. fra Oplonti e Stabiae nel quadro dell'evoluzione olocenica della Piana del Sarno (Campania). Bollettino della Società Geologica Italiana. 1986;105(1-2):111-121.

5. Malandrino C. Il "pagus" marittimo di Pompei: Note di topografia antica. In: D’Amelio, editor. Torre Annunziata; 1988.

6. Furnari E. Nuovi contributi all'identificazione del litorale antico di Pompei. In, Neapolis. Roma.Temi progettuali II, 219-291 p.

7. Pescatore T, Senatore MR, Capretto G, et al. Ricostruzione paleogeografia delle aree circostanti l'antica città di Pompei (Campania, Italia) al tempo dell'eruzione del Vesuvio del 79 d.C. Bollettino della Società Geologica Italiana. 1999;118:243-254.

8. Pescatore T, Senatore MR, Capretto G, et al. Holocene coastal environments near Pompeii before the A.D. 79 eruption of Mount Vesuvius, Italy. Quaternary Research. 2001;55(1):77-85.
9. Ciarallo A, Pescatore T, Senatore MR, et al. Su di un antico corso d'acqua a nord di Pompei. Dati preliminari. Rivista di Studi Pompeiani. 2003;14:274-283.

10. Vogel S, Marker M. Reconstructing the Roman topography and environmental features of the Sarno River Plain (Italy) before the AD 79 eruption of Somma-Vesuvius. Geomorphology. 2010;115(1-2):67-77.

11. Ciarallo A, De Carolis E, Senatore MR, et al. Water supply and water circulation in ancient Pompeii: resource management and catastrophic events in the past as in the present. Rendiconti Online, Società Geologica Italiana. 2012;21:738-740.

12. Senatore MR, Ciarallo A, Stanley D, et al. Pompeii damaged by volcaniclastic debris flows triggered centuries prior to the 79 A.D. Vesuvius Eruption. Geoachaeology: An International Journal. 2014;29:1-15.

13. Senatore MR, Falco M, Meo A, et al. The Water Supply System of Ancient Pompeii (Southern Italy): From Resource to Geohazard. In: Arvin Farid, editor. Geohazards Caused by Human Activity, In Tech; 2016.

14. Barra D. La piana del fiume Sarno. Studio del Pleistocene superiore Olocene delle aree vulcaniche campane. Dottorato di ricerca di Geologia del Sedimentario. Consorzio Università di Napoli "Federico II" e di Palermo. Tesi di dottorato. 1991;34-59.

15. Ruggiero M. Del sito di Pompei e dell'antico lido del mare. In, Pompei e la regione sotterrata dal Vesuvio nell'anno LXXIX, Memorie e notizie pubblicate dall'Ufficio Tecnico degli scavi delle provincie meridionali. 1879;5-14.

16. D’Ambrosio A. La stipe votiva in località Bottaro (Pompei). $19^{\circ}$ Centenario dell'eruzione vesuviana del 79 d.C. Università degli Studi di Napoli; 1984.

17. Sakai S. La storia sotto il suolo del 79 d.C. Considerazioni sui dati provenienti dalle attività archeologiche svolte sulle fortificazioni di Pompei. Opuscula Pompeiana. 2001;10:87-100.

18. Matsui S, Sorrentino L, Sakai S, et al. La provenienza dell'acqua potabile nell'antica Pompei: un'ipotesi basata sull'analisi chimica dei residui calcarei degli impianti idrici. Fast Online Documents \& Research. 2009.

19. Stuiver M, Reimer PJ, Bard E, et al. INTCAL98 radiocarbon age calibration, 24,000-0 cal. BP. Radiocarbon. 1998;40(3):1041-1083.

20. Del Prete M, Guadagno FM, Hawkins AB, et al. Preliminary report on the landslides of 5 May 1998, Campania, southern Italy. Bulletin of Engineering Geology and the Environment. 1998;57(2):113-129.

21. Pareschi MT, Favalli M, Giannini F, et al. May 5, 1998, debris flows in circum-Vesuvian areas (southern Italy): Insights for hazard assessment. Geology. 2000;28(7):639-642.

22. Esposito E, Porfido S, Violante C, et al. Il nubifragio dell'ottobre 1954 a Vietri sul Mare-Costa di Amalfi, Salerno. CNR-GNDCI-IAMC; 2004.

23. Ciarallo A, Senatore MR, Stanley D, et al. Il territorio vesuvianonel 79 dC. In:Caio Giulio Polibio - Storie di un cittadino pompeiano. In: Castiglione Morelli V, De Carolis E, editors. Edistampa, Caserta, Italy, 2015;391-405. 